\title{
NKG2D Ligand 1
}

National Cancer Institute

\section{Source}

National Cancer Institute. NKG2D Ligand 1. NCI Thesaurus. Code C105582.

NKG2D ligand 1 (244 aa, $28 \mathrm{kDa}$ ) is encoded by the human ULBP1 gene. This protein is involved in activation of multiple signaling pathways in primary NK cells. 